\title{
State service policy: international experience
}

\section{Abbas Aliyev, Taras Shevchenko National University of Kyiv}

The article analyzes the experience of leading countries in implementing the service policy of the state (Great Britain, France, Germany, Malaysia, etc.) in order to identify effective practices for reforming state policy in the context of its service orientation. The Charter of the Citizen (UK) was adopted in 1991 and was a 10-year improvement program of the public services quality. The main principles of the Charter (standards; openness; choice; politeness and courtesy; providing services properly; efficiency and low cost) were observed.

Moreover, the «Charter on the delivery of public services» (France, 1992) is researched. It presented basic principles of work regulation of French civil service on the basis of equality, impartiality and continuity, as well as new principles of activities, as a reaction to changes in expectations and demands of the population, the emergence of consumers' new needs and requests, the need for transparency and accountability, simplicity and accessibility.

It is proved that the Services Consumer Charter for Public Services in Belgium (1993) is an example of a comprehensive program that seeks to improve the relationship between state bodies and institutions on the one hand and the population - customers and consumers (clients) of services - on the other one.

Analysis of mantioned above and other charters helps to detect the main tasks of the public service systems reforms, in particular: increasing the efficiency of public services and reducing the cost for their delivery; deliivery of services to citizens of the proper quality; reduced deadlines for preparing responses to requests of citizens; conducting external audits to provide creation of a system aimed at continuous improvement; emphasis on achieving results, but their planning; better definition of work processes; improving the quality of informing citizens about public services delivery; openness and transparency of authorities activities; liberalization of licensing institutions; implementation of the «e-government».

A characteristic feature of reforming the system of public services delivery in the countries taken under consideration is detected. This is a duration of this process. The explanation of the long terms of the reforms in the sphere increasing the efficiency of the public sector lies in the complexity and scope of the set goals and objectives, and also in a large number of parties involved in the reform process. The further research of the problematic can be dealt with analysis of the state, quality, and special features of the domestic reforms dedicated to the state service policy implementation.

Keywords: public services, reforms, efficiency, charter, delivery, quality, transperency

\section{Сервісна політика держави: світовий досвід}

\section{Аббас Алієв, Київський національний університет імені Тараса Шевченка}

У статті проаналізовано досвід країн-лідерів із впровадження сервісної політики держави (Австрія, Велика Британія, Франція, Німеччина, Малайзія, Сінгапур тощо) з метою виявлення ефективних практик реформування державної політики у контексті іії сервісної спрямованості. Для дослідження відібрано країни, які репрезентують дві моделі надання публічних послуг (європейська та азійська). Доведено, що обидві демонструють високий рівень якості державних послуг. Виявлено відмінні мотиваційні чинники популяризації сервісної політики у країнах, що представляють ці дві моделі. Свропейська сервісна політика формувалася як відповідь на запити та потреби громадян з метою задоволення їхніх інтересів, азійська - як інструмент посилення інвестиційної привабливості. Стверджується, що у ході соціально-політичних та адміністративних реформ, які відбуваються сьогодні в Україні, вивчення прикладного досвіду сервісної політики країн, що досягли найкращих показників у ії здійсненні, стане у нагоді задля коректного визначення необхідних механізмів та виділення пріоритетних принципів.

Переважно досліджуються прикладні кейси країн-членів СС з урахуванням євроінтеграційної стратегії України. Деталізовано нормативно-правові засади реалізації сервісної політики, виявлено характерні риси та результати практики сервісної діяльності держави у цих країнах.

3'ясовано основні досягнення країн-лідерів з прикладної імплементації сервісної політики: скорочення термінів підготовки відповідей на запити громадян; проведення зовнішнього аудиту 3 метою створення системи, спрямованої на постійне вдосконалення; акцент на досягнення результатів, а не їхнє планування; підвищення якості інформування громадян про надання державних послуг; відкритість та прозорість діяльності органів влади; реалізації «електронного уряду».

Ключові слова: публічні послуги, реформи, ефективність, хартія, надання, якість, прозорість 


\section{Сервисная политика государства: мировой опыт}

\section{Аббас Алиев, Киевский национальный университет имени Тараса Шевченко}

В статье проанализирован опыт стран-лидеров по внедрению сервисной политики государства (Австрия, Великобритания, Франция, Германия, Малайзия, Сингапур и т. д.) с целью выявления эффективных практик реформирования государственной политики в контексте ее сервисной направленности. Для исследования отобрано страны, которые представляют две модели предоставления публичных услуг (европейская и азиатская). Доказано, что обе демонстрируют высокий уровень качества государственных услуг. Выявлено отличительные мотивационные факторы популяризации сервисной политики в странах, представляющих эти две модели. Европейская сервисная политика формировалась как ответ на запросы и потребности граждан в целях удовлетворения их интересов, азиатская - как инструмент усиления инвестиционной привлекательности. Утверждается, что в ходе социально-политических и административных реформ, которые происходят сегодня в Украине, изучение прикладного опыта сервисной политики стран, достигших наилучших показателей в ее осуществлении, пригодится для корректного определения необходимых механизмов и выделение приоритетных принципов.

Преимущественно исследуются прикладные кейсы стран-членов ЕС с учетом евроинтеграционной стратегии Украины. Детализированы нормативно-правовые основы реализации сервисной политики, выявлены характерные черты и результаты практики сервисной деятельности государства в этих странах.

Выяснены основные достижения стран-лидеров по прикладной имплементации сервисной политики: сокращение сроков подготовки ответов на запросы граждан; проведения внешнего аудита с целью создания системы, направленной на постоянное совершенствование; акцент на достижение результатов, а не их планирование; повышение качества информирования граждан о предоставлении государственных услуг; открытость и прозрачность деятельности органов власти; реализации «электронного правительства».

Ключевые слова: публичные услуги, реформы, эффективность, хартия, предоставление, качество, прозрачность

Problem statement and its connection with important scientific or practical tasks.

A number of foreign countries have achieved impressive results in reforming the system of public services delivery. In the late 1980 s, after the cardinal processes of liberalization and privatization in the economy, improving the quality of public services became one of the main priorities of transformation in the authority system and public service. It should be noted, that the forms and methods of reforms differ from country to country, taking into account the features of the state system, as well as national, cultural and historical traditions. However, the principle of orientation to the ordinary consumer of public services remained unchanged. The countries where these changes were fully implemented, had the most successful reforms.

Analysis of recent researches and publications on the topic.

There are many scientific papers devoted to the study of the essence, mechanisms and principles of state service policy (E. Ferlie [8], P. Klimushin [1], A. Maltsev [2], V. Missura [3], C. Pollitt [9]). At the same time, there is a significant lack of deep researches connected to the study of the positive experience of implementation of service policy based on specific cases. That is why this topic of the scientific article was chosen.

The goal of the article is a systematical analysis of the experience of foreign countries in the process of state service policy implementation, and detection of leading countries in this process.

\section{Presentation of the main research material.}

The research suggests a case study of public service delivery in The UK, France, Germany, etc., as well as Singapore and Malaysia, according to the highest results achieved by these countries in the field of public service delivery. The two models (European and Asian ones) were chosen, as they demonstrate two different motivations in quality public service delivery promotion. The goal of the European model was a pure intention to improve the quality of public services in order to satisfy customers. The Asian model was driven by the necessity to attract investments to the countries. The mechanisms and principles were completely the same, yet the goals were different. Therefore, the experience of both these models could be useful for the Ukrainian public sector reforms, as it can supply the Ukrainian reformers with a ready-made toolkit for productive changes in the sphere of public service delivery. Accept for that, it could help decide 
upon real motivation for such changes. Besides, the European model was chosen in the context of the Ukrainian integration into the EU.

The United Kingdom gives a successful example of how the task of providing citizens with public services and ensuring the quality of these services should be implemented. In 1991, at the initiative of the Prime Minister of Great Britain, J. Major, the country adopted the Charter of the Citizen familiar to the famous Magna Carta (1215).

The charter was a 10-year improvement program of the public services quality: their approximation to the needs and requirements of citizens of the United Kingdom. The key idea of the Charter was not inventing some new rights for citizens by politicians, yet the conscientious fulfillment of duties by public servants. However, that was the first governmental document, dedicated to the problem of public services, which defined principles, scope and specific objectives of the program. The main principles of the Citizen's Charter are:

standards: standards are set, monitored and published, so that users can know what they can get from the state;

- openness: information about services should be complete, accurate, understandable, with a clear indication of who is responsible for the delivery of a particular service, how these services are provided and what is their value;

- choice: the choice of service should be provided wherever it is possible, and implemented in agreement with the users;

politeness and courtesy: services must be accessible to all the citizens equally, and civil servants must pin up cards to their clothes with their names and surnames;

- providing services properly: otherwise state employees must explain the logic of their actions to users or apologize; a clear procedure for appealing against their actions also must be established;

- efficiency and low cost: the delivery of services should not go beyond budget allocations and demonstrate the best balance between the quality of the service and its price [5].

After the adoption of the general charter, the government developed special ones. Among them there were:

- Patient charter;

- Taxpayer charter;

- Donor charter;

- Students' parents charter;

- Victims of crime charter.
The results of the implementation of theses charters can be presented as follows:

- all charters record the standards applied in the delivery of a specific service, and ways to appeal against the actions of public servants;

- each charter is a subject of permament improvement;

- updated versions are published annually;

- the charters contribute to enhancing the transparency and openness of public institutions, making service providers directly and personally accountable to their clients;

- anonymity of officials contacting directly with citizens was eliminated; nowadays service consumers know the names of employees conducting the delivery of each specific service;

- majority of government agencies regularly conduct surveys of their clients and publish the results; some departments even organize "doorto-door" campaigns in order to learn the opinion of citizens about their activities in the delivery of services directly;

-in order to reduce the time for consideration of complaints, the relevant rules were revised, the procedures for awarding compensation were simplified, greater impartiality was reached in adjudicating complaints, for example, through the usage of independent judges;

- inspection instances of some public institutions, for example, the police, schools, prisons, courts, etc., began to be completed with ordinary citizens;

- a system of awarding civil servants, known as Charter Marks was implemented: according to this system, employees of the most basic structures who are located at the micro level of service delivery are rewarded (schools, hospitals, social services);

- a new bonus system for top managers was also introduced, associating their remuneration with the delivery of cost-effective and efficient services [4].

The development of a charters system followed the need to study the level of satisfaction of consumers of public services, which today should be considered as the basis for assessing the achievements of the public service organization, measuring the effectiveness of public administration. At the same time, the emphasis began to shift from the initial development of the «entry» standards (for example, how much time patients have to wait for hospitalization) to the «exit» standards (for example, the level of education received by students).

The charter policy was continued by all of the subsequent governments. By the way, the government of T. Blair gave the Charter of Citizens a new name - 
"Service - first and foremost". In 1998, a new charters program was adopted. Its goal was to improve the delivery of public services based on achieved in previous years results. New program features dealt with the focus on responsiveness, quality, efficiency, and an inter-agency approach. As noted in 2002 by T. Blair, the first term of his office in power, was devoted to the creation of a reliable economic bases for reforming the system of public services. When this goal was achieved, the modernization of public services beacme key task of the whole complex of problems facing the British government [11].

In 1992, the Council of Ministers of France adopted the "Charter on the delivery of public services», which presented basic principles of activity regulation of French civil service on the basis of equality, impartiality and continuity, as well as new principles of activities, as a reaction to changes in expectations and demands of the population, the emergence of consumers' new needs and requests, the need for transparency and accountability, simplicity and accessibility.

The Services Consumer Charter for Public Services in Belgium (1993) is an example of a comprehensive program that seeks to improve the relationship between state bodies and institutions on the one hand and the population - customers and consumers (clients) of services - on the other one.

In 1993, Portugal adopted the "Charter of Quality of Public Services», which extended to all services of the central government and municipal authorities. The basic principles declared by this document dealt with the accountability of the commissioners for services delivery to individuals, transparency of these procedures, citizens' participation in competitions, etc.

Analysis of these charters helps to detect the main tasks of the public service systems reforms, in particular:

- increasing the efficiency of public services and reducing the cost of their delivery;

- delivery of proper quality services to citizens;

- reduced deadlines for preparing responses to citizens' requests;

- conducting of external audits to provide creation of a system aimed at continuous improvement;

- emphasis on achieving results, not their planning;

- better definition of work processes;

- improving the quality of citizens informing on available public services;
- openness and transparency of public institutions activities;

- liberalization of licensing institutions;

- implementation of the «e-government» [7].

The charters also contained a description of services, standards, which applied in delivery of one or another services; criteria for assessing the quality of services, mechanisms for appealing actions of civil servants. At the same time, in the process of conducting reforms in Western European countries the system of awarding public servants for effective work was introduced.

The tasks of optimizing the delivery of public services were solved with the usage of such tools as the creation of integrated services delivery centers working on the principle of a «single window»; the transition to the delivery of public services in electronic form, the creation of call centers and contact centers for the organization of interaction with citizens, the creation of mobile public service offices, etc.

It should be noted that the most complete classification of the public services spectrum is developed in Germany. Federal public services ( $\approx 400$ subtypes) are classified into 8 types according to the content, and $73 \%$ of the total number of services belong only to the three of them, namely: collection, processing and providing general and specialized information, processing applications and appeals to the public authorities, as well as provision assistance in obtaining various forms of financial assistance, participation in contests, and grants receiving, etc.

In Austria there is a General Law on the administrative procedure, in Estonia - a number of laws on the administrative procedure, in Poland the Code of Administrative Procedure, according to which the needs of the population in services are satisfied either by providing appropriate services by the authorities themselves, or by means of concluding agreements on their delivery with private contractors [6].

In most of the new EU member states (Latvia, Czech Republic, Hungary) the laws «On Local Authorities» were adopted and are in force, according to them, local self-government bodies have the right to solve the problems and respond the needs of the local people independently, as well as through organization and financing of processes and procedures for the delivery of municipal services.

For example, according to the Law of Latvia «On local authorities», one of the main functions is to deliver high-quality municipal services to the 
population, and the legislation of most EU countries delineates municipal services according to the two criteria: mandatory and optional ones. At the same time, bodies of self-government have the right to decide on issues concerning providing and financing services that are not stipulated by law. Therefore, in Poland municipalities meet the needs of the local population through the delivery of certain services at the local level (transport service, exportation, rubbish, etc.) or enter into agreements regarding providing these services by private contractors.

In Singapore, in 1995, the government adopted the program «Public Service in the 21st Century» (PS21). According to it, a number of changes in the delivery of public services was held. So, every ministry / agency in Singapore has own quality manager, who is always available to consumers and their complaints. In 2004, the «No Wrong Door» program was adopted, which obliges all agencies to have contacts with other agencies, so that citizens do not have to turn from one agency to another one in the search for answers to their questions. Receiving the services of each executive body consumers estimate time spent on receiving a service, filling different forms, etc. This motivates agencies to analyze critically this information and encourages them to reduce operations to minimum.

To establish a stable level of service quality in all the agencies, guidelines for the delivery of services, such as service standards, feedback and communication with the society, consultations and others were developed. Each agency should meet the requirements of the standards. Standards should be audited and reviewed regularly to ensure that they are maintained at a high level. The society is constantly interviewed in order to determine its perception of the level of services delivered by various agencies.

Since 2003, in Singapore an annual award for high-quality public services - "Star Service Awards" has been awarded to officials who regularly show outstanding results in public services delivery.

An electronic resource of the Singapore government through which citizens could get know the categories of available e-services was launched in 1999 [10]. Then, during 2000-2006, there was a preparation for the launch of e-government services. The launch was conducted within the framework of the program iGov2010, in 20062010. Within it more than 50 public agencies were introduced. For business and citizens, more than 1,600 online services are available on the Singapore Governmental portal (http://www.gov.sg).
A survey of 2,800 respondents at the end of the eGov2010 program showed that 9 out of 10 Singapore citizens were satisfied with the work of e-government services and $93 \%$ were ready to recommend using them for interaction with public agencies [10].

InMalaysia since the early 80's there were reforms carried out within the framework of modernization of the system of public administration and public service delivery. Much attention was paid to the creation of necessary regulatory and legal framework regulating service activities, and in 1993 the government adopted a Service Charter. Reforms on improving the quality of public services in Malaysia were held by an Administrative modernization and management planning department formed as an Office of the Prime Minister. Its main task is to carry out administrative reforms in order to increase quality of public services and public administration performance. To do this, special guideline was developed («Circulars on the development of administration»). It described in detail the steps that must be taken by public organizations to improve the quality of their services.

To promote the achievement of high results in this area, a developed system of incentives was implemented in Malaysia. It became a basis on which quality awards are awarded at different levels of management. The most important among them is the «Prime Minister's Quality Award», which means recognition of high quality level of services for public and private organizations. As in other countries, in Malaysia, there were reforms related to the implementation of the «e-government» and the system of e-public services. Its introduction was conducted by MAMPU, which task was not only an organization of effective internal and interdepartmental interaction, but also aimed at simplifying the on-line access of entrepreneurs and citizens to public services. Several pilot projects on the delivery of services through the Internet were initiated: registration of cars, issuance of driver's licenses; payment for utilities; information provided by the Ministry of Health; implementation of government procurement; electronic labor exchange. Measures applied in this area are included in the five-year development plan of the country and the Malaysian Strategic Plan «Perspective 2020».

\section{Conclusions and prospects for further} researches.

The analysis of the mentioned above information makes it possible to understand that the experience of developed, socially 
responsible countries of the West Europe and Asia clearly demonstrates that managerial activity of bureaucracy will be effective only when it is conducted on the grounds of conceptually newest knowledge of man, society and state, principles and patterns of their development, modern organizational innovations, innovative management technologies, organizational mechanisms and tools, opportunities and potential of modern information and computer technologies usage in the processes of governance and collaboration with the population, etc.

When carrying out the reforms in the sphere of public services delivery the modernization of the infrastructure of the public services delivery system was started to achieve sustainable outcomes. It included the creation of a network of organizations and institutions in the form of service centers for the population facilitating the process of delivery of public services on a one-stop-shop basis, creation of public service web portals, provision of consultations and training for both civil servants and services consumers.

A characteristic feature of reforming the system of public services delivery in the countries taken under consideration is duration of this process. For example, the Citizens Charter (UK) was designed for 10 years, but the improvement of the individual components of this system continues until now. The explanation of the long terms of the reforms in the sphere increasing the efficiency of the public sector lies in the complexity and scope of the set goals and objectives, and also in a large number of parties involved in the reform process. The further research of the problematic can be connected with an analysis of the status, quality, and special features of the domestic reforms dedicated to the state service policy implementation.

\section{БІБІЛІОГРАФІЧНІ ПОСИЛАННЯ}

1. Клімушин П., Спасібов Д. Концепція сервісно орієнтованої держави в контексті модернізації публічного управління. - Режим доступу: http://www.kbuapa.kharkov.ua/e-book/tpdu/2017-2/doc/1/03.pdf.

2. Мальцев А. Клиентоориентированный подход в бизнесе и в государственном (муниципальном) управлении. Власть. 2011. № 10. С. 24-29.

3. Місюра В. Сучасні напрями формування та реалізації соціально орієнтованої сервісної політики держави. Режим доступу: file://C:/Users/dell\%2015z/Downloads/znpnadu_2015_2_11.pdf.

4. Реформа государственного управления: международный опыт. Отв. ред. Ник Мэннинг, Нил Парисон. М., 2003. 5. Садлер Дж. Повышение качества государственных услуг: опыт Великобритании. - Режим доступу: http:// vasilievaa.narod.ru/ptpu/10 3 00.htm.

6. Скороход О.П. Надання послуг населенню органами місцевого самоврядування як пріоритет діяльності місцевої громади. Стратег. пріоритети. 2010. No1. С. 41-46.

7. Фурщик М. А., Кураш А. П. Влияние технологий государственного управления на экономическое развитие. Менеджмент и бизнес-администрирование. 2010. №2. С. 36-47.

8. Ferlie E. The New Public Management in Action. Oxford, Oxford University Press, 1996. 298 p.

9. Pollitt C. Public Management Reform: A Comparative Analysis. Oxford, Oxford University Press, 2000. 392 p.

10. Public service reforms in Singapore. - Access: www.sce.gov.sg/pdfs/printouts.

11. Reforming our public services: principles into practice. March 2002. - Access: http://www.cabinetoffice.gov.uk

\section{REFERENCES}

1. Klimushyn P., Spasibov D. (2017). Kontseptsiia servisno oriientovanoi derzhavy v konteksti modernizatsii publichnoho upravlinnia [The concept of a service-oriented state in the context of modernizing public administration]. Available at <http://www.kbuapa.kharkov.ua/e-book/tpdu/2017-2/doc/1/03.pdf $>$.

2. Maltsev A. (2011). Klyentooryentyrovannyi podkhod v byznese y v hosudarstvennom (munytsypalnom) upravlenyy [Customer-oriented approach in business and in state (municipal) management]. Vlast. № 10. S. 24-29.

3. Misiura V (2015). Suchasni napriamy formuvannia ta realizatsii sotsialno oriientovanoi servisnoi polityky derzhavy [Modern directions of formation and realization of socially oriented service policy of the state]. Available at $<$ file://C:/ Users/dell\%2015z/Downloads/znpnadu_2015_2_11.pdf>.

4. Reforma hosudarstvennoho upravlenyia: $\bar{m} e \bar{h}$ dunarodnyi opyt [Reform of public administration: international experience] (2003). Otv. red. Nyk Mennynh, Nyl Paryson. M.

5. Sadler Dzh. (1999). Povyshenye kachestva hosudarstvennykh usluh: opyt Velykobrytanyy [Improving the quality of public services: the UK experience]. Available at $<\mathrm{http}: / /$ vasilievaa.narod.ru/ptpu/10_3_00.htm $>$.

6. Skorokhod O.P. (2010). Nadannia posluh naselenniu orhanamy mistsevoho samovriaduvannia yak priorytet diialnosti mistsevoi hromady [Providing services to the population by local government bodies as a priority of the local community activity]. Strateh. priorytety. No1. S. 41-46. 
7. Furshchyk M. A., Kurash A. P. (2010). Vlyianye tekhnolohyi hosudarstvennoho upravlenyia na ekonomycheskoe razvytye [The Impact of Public Administration Technologies on Economic Development]. Menedzhment y byznesadmynystryrovanye. №2. S. 36-47.

8. Ferlie E. (1996). The New Public Management in Action. Oxford, Oxford University Press.

9. Pollitt C. (2000). Public Management Reform: A Comparative Analysis. Oxford, Oxford University Press.

10. Public service reforms in Singapore. Available at $<$ www.sce.gov.sg/pdfs/printouts $>$.

11. Reforming our public services: principles into practice (2002). Available at $<$ http://www.cabinetoffice.gov.uk $>$.

\author{
Алісв Аббас Мамед огли \\ Аспірант \\ Київський національний університет імені Тараса Шевченка \\ 01601, Київ, вул. Володимирська, 60
}

\author{
Aliyev Abbas \\ Postgraduate Student \\ Taras Shevchenko National University of Kyiv \\ 60, Volodymyrska Str., 01601, Kyiv, Ukraine \\ Email: aliyev_abbas@ukr.net ORCID: 0000-0002-4980-7492
}

Цитування: Aliyev A. State service policy: international experience / A. Aliyev // Scientific and theoretical almanac «Grani». - 2019. - Vol. 22, № 1. - P. 20-28.

Citation: Aliyev, A. (2019). State service policy: international experience. Scientific and theoretical almanac «Grani», 22(1), 20-28.

Стаття надійшла / Article arrived: 23.12.2018

Схвалено до друку / Accepted: 24.01.2019 